NBER WORKING PAPER SERIES

\title{
THE SUPER SIZE OF AMERICA: AN ECONOMIC ESTIMATION OF BODY MASS INDEX AND OBESITY IN ADULTS
}

\author{
Inas Rashad \\ Michael Grossman \\ Shin-Yi Chou \\ Working Paper 11584 \\ http://www.nber.org/papers/w11584
}

\section{NATIONAL BUREAU OF ECONOMIC RESEARCH 1050 Massachusetts Avenue Cambridge, MA 02138}

August 2005

The views expressed herein are those of the author(s) and do not necessarily reflect the views of the National Bureau of Economic Research.

(C)2005 by Inas Rashad, Michael Grossman and Shin-Yi Chou. All rights reserved. Short sections of text, not to exceed two paragraphs, may be quoted without explicit permission provided that full credit, including (C) notice, is given to the source. 
The Super Size of America: An Economic Estimation of Body Mass Index and Obesity in Adults Inas Rashad, Michael Grossman and Shin-Yi Chou

NBER Working Paper No. 11584

August 2005

JEL No. I10, I12

\section{$\underline{\text { ABSTRACT }}$}

The increased prevalence of obesity in the United States stresses the pressing need for answers as to why this rapid rise has occurred. This paper employs micro-level data from the First, Second, and Third National Health and Nutrition Examination Surveys to determine the effects that various state-level variables have on body mass index and obesity. These variables, which include the per capita number of restaurants, the gasoline tax, the cigarette tax, and clean indoor air laws, display many of the expected effects on obesity and explain a substantial amount of its trend. These findings control for individual-level measures of household income, years of formal schooling completed, and marital status.

Inas Rashad

Department of Economics

Georgia State University

PO Box 3992

Atlanta, GA 30302-3992

irashsad@gsu.edu

Michael Grossman

CUNY Graduate Center

365 Fifth Avenue, $5^{\text {th }}$ Floor

New York, NY 10016-4309

and NBER

mgrossman@gc.cuny.edu

Shin-Yi Chou

Department of Economics

Lehigh University

621 Taylor Street

Bethlehem, PA 18015

and NBER

syc2@lehigh.edu 
"The drudgery of seeking subsistence has been supplanted for millions of people, not by abundance and indulgence, but rather by a new concept of what are necessities and needs."

- George Katona, The Mass Consumption Society (1964, p.6)

\section{Introduction}

The New York Times recently featured in its Book Review a book by Greg Critser entitled How

Americans Became the Fattest People in the World, further shedding light on the obesity epidemic that has been prominently featured in the media. While obesity is not a new problem, it has recently surged into public consciousness. For most individuals, overweight and obesity result from a combination of excess caloric intake and inactivity (Koplan and Dietz 1999; Public Health Service 2001). The majority of Americans are now overweight (Must et al. 1999; Flegal et al. 2002). According to the USDA, Americans consumed 2,002 calories per day in 1994-1996, as opposed to 1,854 in 1977-1978 (Frazao 1999). While rates of overweight and obesity had remained steady until about 1980, since then overweight and obesity in the United States have escalated dramatically. This is an indication that genetics may not play such a large role in obesity, as genetic change does not occur so rapidly over time. According to Koplan and Dietz (1999), the gene pool in the US has not changed significantly between 1980 and 1994. A study using twins has indicated that perhaps there is a much larger environmental effect in determining body weight than previously believed (Segal and Allison 2002).

Second only to tobacco as the leading cause of premature death (McGinnis 1993), obesity and sedentary lifestyle are rapidly becoming the first. Obesity and sedentary lifestyles accounted for approximately 400,000 deaths in 2000, compared to 435,000 from cigarette smoking, 100,000 from alcohol abuse, and 20,000 from illegal drug use. They are related to such illnesses as coronary heart disease, stroke, high blood pressure, cancers of the colon, breast and prostate, and diabetes (Must et al. 1999; Mokdad et al. 2003). Obesity has also been associated with high cholesterol, menstrual irregularities, pregnancy complications, and psychological disorders such as depression (NIDDKD 1996). Known to many as adult-onset diabetes, type 2 diabetes is now not uncommon among children as a result of the obesity epidemic (Freedman et al. 1999). Obesity in adulthood has been shown to reduce life expectancy, most notably at younger ages (Peeters et al. 2003; Fontaine et al. 2003). 
This paper investigates the idea that the recent rapid increase in obesity rates are due to economic changes that have in turn caused behavioral changes in the lives of Americans. These changes in the environment have changed habits and redefined social and cultural norms. Changes in the surrounding environment have been numerous. The per capita number of restaurants increased by 61 percent between 1972 and 1997 (see Figure 1). Since more women are in the labor force today than in the 1970s, eating out has become more common as families are encouraged to purchase food away from home. ${ }^{1}$ Figure 2 shows the trend in female labor force participation in the US from 1970 to 2000 . In 1971, 43 percent of women were in the labor force, a figure which increased to almost 60 percent by 1994 . Technological changes have made for an easier lifestyle, and thus less physical activity is embedded into daily activities. Jobs have become more sedentary, contributing to the lack of physical activity that many experience. Many must now stray from their daily routines and pay for gym memberships in order to be more physically active.

To study the determinants of body mass index and obesity, we employ pooled micro-level data from the First, Second, and Third National Health and Nutrition Examination Surveys. These data, described later in full, are what the Centers for Disease Control use to track changes in obesity over time, as they contain measures of weight and height based on actual physical examinations. We augment these data using state-level policy variables pertaining to the per capita number of restaurants, the gasoline tax, the cigarette tax, and clean indoor air laws. We find that the increase in the per capita number of restaurants in particular increases obesity, and that female body mass index is responsive to changes in the cigarette tax.

\section{Background and Literature Review}

\footnotetext{
${ }^{1}$ While Cutler et al. (2003) say that the shift to more households with women working accounts for a mere ten percent of the increase in obesity, there is an additional indirect effect on other households through cultural changes via externalities. Using international cross-sectional data from 22 OECD countries, they find no effect of the percentage of females in the labor force on obesity.
} 
The prevalence of morbid obesity, the most severe form of obesity defined by a body mass index of 40 $\mathrm{kg} / \mathrm{m}^{2}$ or higher, increased from $0.78 \%$ in 1990 to $2.2 \%$ in 2000 (Freedman et al. 2002). ${ }^{2}$ The body mass index (BMI) is the most convenient measure available in assessing overweight and obesity, its limitations being that it might overestimate body fat in athletes who have a muscular build and underestimate body fat in older people who have lost muscle mass (NIDDKD 1996). ${ }^{3}$ Table 1 shows how average BMI and the percentage obese have changed over time in the four NHANES data sets. ${ }^{4}$ The change between NHANES II and NHANES III is most notable, where a 57\% increase occurs in the percentage of people who are obese. Average BMI goes up by $1.28 \mathrm{~kg} / \mathrm{m}^{2}$, or $5.1 \%$, from $25.07 \mathrm{~kg} / \mathrm{m}^{2}$ to $26.35 \mathrm{~kg} / \mathrm{m}^{2}$. Table 2 shows differences across gender. This shows a $127 \%$ increase in the percentage of obese males between NHANES I and NHANES 99, and a 106\% increase for females. The percentage of obese females, however, has remained consistently higher than the percentage of obese males.

Part of the tremendous increase in the obesity rate over time has been attributed to reductions in job strenuousness (Philipson 2001; Lakdawalla and Philipson 2002). Lakdawalla and Philipson use the National Health Interview Survey (1976-1994) and the National Longitudinal Survey of Youth (19821998) to show that decreases in job strenuousness over a long period of time are mainly responsible for increases in BMI over time. However, job strenuousness was relatively stable between the NHANES II and NHANES III time periods. The authors explain the rapid increase in the last two decades with changes in food prices. One disadvantage is that they are forced to use self-reported measures of weight and height rather than actual measures, yet they do attempt to correct for this. ${ }^{5}$ Philipson (2001) points

\footnotetext{
${ }^{2}$ This estimate is based on self-reported measures from the Behavioral Risk Factor Surveillance System.

${ }^{3}$ Waist circumference might be an alternate measure of obesity, as a waist circumference of over 35 inches for women and 40 inches for men has been associated with a markedly increased likelihood of a variety of diseases (Janssen et al. 2002). However, waist circumference is not commonly measured in national public health data sets, and only NHANES III measures waist circumference.

${ }^{4}$ We do not use the most recent NHANES data in our analysis as the most current data available for the number of restaurants from the Census of Retail Trade is in 1997.

${ }^{5}$ This method uses NHANES data, which contains both self-reported and actual measures of height and weight, and obtains age-gender-race-specific corrections. This is done by regressing the actual measure on the self-reported measure and its square and using the coefficient to adjust the self-reported measures in the data set being used. This is also the method used by Chou, Grossman, and Saffer (2004) in their study using the BRFSS. Yet there have been arguments that even this correction does not completely eliminate error and is not a perfect substitute for actual measures (see, for example, Plankey et al. 1997).
} 
out that the American society has shifted from an agricultural one to a post-industrial one. This shift has been accompanied by innovations that economize on time spent in the household sector, such as convenience food for consumption. An increase in the variety of the food supply may contribute to the maintenance of obesity (Raynor and Epstein 2001).

Cawley (1999) has presented evidence suggesting that caloric intake is addictive. This is in line with findings that high-density fast food might indeed be addictive (Naik and Moore 1996; Schlosser 2001). Fat consumption in the US has increased (Ippolito and Mathios 1995; Frazao 1999). Evidence has also been put forth suggesting that obesity is associated with lower wages for women (Averett and Korenman 1996; Cawley 2004). The negative externalities that obese people impose on others has also been considered (Keeler et al. 1989). ${ }^{6}$

Chou, Grossman, and Saffer $(2002,2004)$ employ micro-level data from the 1984-1999 Behavioral Risk Factor Surveillance System to show the determinants of body mass index and obesity. They find large positive elasticities associated with the per capita number of restaurants, and at the same time, direct positive effects of labor market attachment on obesity. They theorize that perhaps labor market attachment has indirect effects on obesity that operate through restaurant availability. Ewing et al. (2003) have attributed part of the increase in obesity to the degree of urban sprawl. Urban sprawl measures the process through which the spread of development across the landscape outpaces population growth. Using a more comprehensive measure of urban sprawl, Smart Growth America has calculated a reliable measure of how conducive a city is to exercise. Those urban areas that offer more transportation choices, are more compact, and have a variety of stores and activity centers within reach have lower rates of obesity.

Global comparisons can be seen in Cutler et al. (2003), highlighting the leading role that the United States plays in the obesity epidemic. They stress a theory of increased obesity based on the division of labor in food preparation and thus reductions in the time cost of food. The mass preparation of

\footnotetext{
${ }^{6}$ For a further discussion on possible grounds for government intervention in the obesity epidemic, see Rashad and Grossman (2004).
} 
food has allowed for the reduction of the marginal cost of preparing food by substituting capital for labor, leading to repeated food consumption of greater variety. They postulate that fattening meals at fast food restaurants have not made Americans obese as most of the increase in food consumption has been due to increased snacking. ${ }^{7}$

The magnitude of the obesity epidemic begs the question as to why the increase has been so rapid, as well as what policy changes might be done in order to reverse this trend. Part of this question has been answered by previous research. This paper uses comprehensive data rich in covariates with objective measures covering a long time period, 1971-1994. In addition, we consider gender groups separately.

\section{Empirical Methodology}

A household utility function such as that outlined by Becker (1965) provides a useful framework for assessing body mass index. While no one wishes to be obese, some people gain more utility out of consuming food than others. People combine the obtaining of goods and services in the market with their own time to achieve objects that enter their utility functions - such as health, entertainment, and the enjoyment of eating palatable food.

In this paper we use the National Health and Nutrition Examination Survey, which has an advantage over other data sets in that it has actual measures of body mass index rather than self-reported measures. We use pooled data from 1971 to 1994.

Obesity $(O)$ is a function of caloric intake, caloric expenditure, smoking, and a vector of variables that are specific to an individual and reflect that individual's predisposition towards obesity. Demand functions for caloric intake, caloric expenditure, and smoking are generated that depend on a set of exogenous variables as follows:

$$
O=O\left(R, t_{c}, \text { indoor }, t_{g}, E, A, G, S, H, M\right)
$$

\footnotetext{
${ }^{7}$ This conclusion was made using data from the Continuing Survey of Food Intake, and does not take into account snacks purchased at restaurants and consumed at home.
} 
In equation (1), $R$ represents restaurants, $t_{c}$ is the cigarette tax, indoor represents clean indoor air laws, $t_{g}$ is the tax on gasoline, $E$ represents ethnic and racial background, $A$ is age, $G$ is gender, $S$ denotes years of formal schooling completed, $H$ is household income, and $M$ represents marital status. We translate equation (1) into an empirical one through the following equation:

$$
\begin{aligned}
& O=\alpha_{0}+\alpha_{1} R+\alpha_{2} R^{2}+\alpha_{3} t_{c}+\alpha_{4} t_{c}{ }^{2}+\alpha_{5} \text { indoor }+\alpha_{6} t_{g}+\alpha_{7} t_{g}{ }^{2}+\alpha_{8} \text { black } \\
& +\alpha_{9} \text { hispanic }+\alpha_{10} \text { other }+\alpha_{11} A+\alpha_{12} A^{2}+\alpha_{13} \text { male }+\alpha_{14} \text { elem }+\alpha_{15} \text { somehigh } \\
& +\alpha_{16} \text { high }+\alpha_{17} \text { somecoll }+\alpha_{18} \text { college }+\alpha_{19} H+\alpha_{20} H^{2}+\alpha_{21} \text { married } \\
& +\alpha_{22} \text { divorced }+\alpha_{23} \text { widowed }+\overline{\alpha_{24}}(\text { years })+\overline{\alpha_{25}}(\text { states })+u
\end{aligned}
$$

Quadratic terms are included in equation (2) for the per capita number of restaurants, as well as for taxes, income, and age. This is to account for the likelihood that an additional value at higher levels will have less of an effect on the dependent variables as that of an additional value at lower levels. ${ }^{8}$ Black, hispanic, and other are dummy variables for race and ethnicity; male is a dummy variable for whether or not the respondent is male; elem, somehigh, high, somecoll, and college are dummy variables for years of schooling completed; married, divorced, and widowed are dummy variables for marital status; years and states represent indicators for year of survey and state of residence, respectively; $\alpha_{24}$ and $\alpha_{25}$ thus represent vectors.

\section{Micro-Level Data}

To investigate the determinants of body mass index and obesity, we employ micro-level data from the First, Second, and Third National Health and Nutrition Examination Surveys (NHANES I, II, and III, respectively). These are national samples of the population of the US ages 6 months to 74 years (NHANES I and II), and ages 2 months and over (NHANES III) with some oversampling of preschool children and the elderly in all three surveys; low-income families in NHANES I and II; women of childbearing ages in NHANES I; and blacks and Mexican Americans in NHANES III. The oversampling of low-income families in NHANES I and II results in the presence of more blacks in these surveys than

\footnotetext{
${ }^{8}$ In preliminary regressions, we find evidence that these continuous variables - the only continuous variables on the RHS with the exception of indoor, which takes on only four values, have non-linear effects.
} 
in a random sample of the population of the US. Similarly, the oversampling of blacks and Mexican Americans in NHANES III results in more low-income families than in a random sample. We focus in this paper on all adults 17 years of age and older. All three surveys were conducted by the National Center for Health Statistics (NCHS); NHANES I was conducted between 1971 and 1975; NHANES II was conducted between 1976 and 1980; and NHANES III was conducted between 1988 and 1994. Most states of the US are represented in each survey.

\section{Dependent Variables}

Body mass index (BMI), also termed Quetelet's index, is measured as weight in kilograms divided by height in meters squared, and is most commonly used in analyzing overweight and obesity. While there are various guidelines for defining overweight and obesity, we adopt the convention outlined by the National Institutes of Health in Clinical Guidelines (Public Health Service 2001). Following this method, an adult that is overweight is one with a BMI of $25 \mathrm{~kg} / \mathrm{m}^{2}$ or higher, while one that is obese has a BMI of $30 \mathrm{~kg} / \mathrm{m}^{2}$ or higher. Obesity characterized by a BMI between $30-34.9$ is termed class 1 obesity, that between $35-39.9$ class 2 obesity, and that greater than $40 \mathrm{~kg} / \mathrm{m}^{2}$ class 3 obesity, or morbid obesity. The dependent variables that we use are body mass index and the probability of being obese, where an obese respondent is one with a BMI of $30 \mathrm{~kg} / \mathrm{m}^{2}$ or higher.

\section{Independent Variables}

The state-level variables included on the RHS of the equation pertain to the per capita number of restaurants, the cigarette tax, clean indoor air laws, and the gasoline tax. Including more state-level variables would cause the model to be plagued by multicollinearity. We must thus be partial to our results and generalize our conclusions to include effects of state-level variables that might be highly correlated with the ones that we include in our model.

The per capita state-level number of restaurants is taken from the Census of Retail Trade. Frequency of fast food restaurant use has been shown to be associated with higher fat intake and greater body weight (French et al. 2000; Rolls and Hammer 1995; Public Health Service 2001), as fast food restaurants serve especially large portions (Nielsen and Popkin 2003). The Census of Retail Trade is part 
of the Economic Census and is collected every five years. The data we use are from 1972, 1977, 1982, 1987, 1992, and 1997. Fast food restaurants correspond to the Census category refreshment places while full service restaurants correspond to the Census category restaurants and lunchrooms. In 1997 this classification system changed; refreshment places became limited service restaurants, and restaurants and lunchrooms became full service restaurants. Since these categories did not exactly overlap, a correction was used based on national data that the Census collected for both categories. This correction thus involved multiplying the 1997 state-level values for limited service restaurants by the ratio of nationwide refreshment places to limited service restaurants. Similarly, 1997 state-level values for full service restaurants were altered by multiplying these values by the national ratio of restaurants and lunchrooms to full service restaurants. Data for years not covered are linearly interpolated and extrapolated. The distinction between fast food and full service restaurants in the Census of Retail Trade is not clear-cut; many full service restaurants serve the type of high-caloric, inexpensive food that fast food restaurants serve. Therefore, our restaurant variable takes the sum of fast food restaurants, where in general people pay before eating, and full service restaurants, which in general provide waiter/waitress service.

State taxes on gasoline are obtained from Facts and Figures on Government Finance. The interpretation of the effect that the gasoline tax has on obesity can be looked at from two angles. On the one hand increases in the gasoline tax could encourage people to walk and be more physically active. On the other hand increases could be a proxy for increases in the time cost associated with traveling in order to obtain healthy food. This could in turn encourage people to consume cheap, high-density convenience food.

Included among the RHS variables are state cigarette taxes and clean indoor air laws. The cigarette tax is taken from the Tax Burden on Tobacco. Clean indoor air laws are taken from the Centers for Disease Control and Prevention website (http://www.cdc.gov). The four indoor air laws pertaining to government workplaces, private workplaces, restaurants, and other places, are summed to form one variable. We expect cigarette taxes to be a positive function of BMI, as smoking has been used as a method of weight control (Fehily et al. 1984; Tomeo et al. 1999). A combination of federal and state tax 
hikes, clean indoor air laws forbidding smoking in designated areas, and the anti-smoking campaign have caused people to smoke less over time. This may be part of the reason for the increase in BMI over time, an unintended consequence of the anti-smoking campaign.

Medical science has established the effects of caloric intake and physical activity on body mass index, and caloric intake and physical activity are poorly measured in $\mathrm{NHANES}^{9}$; we therefore estimate reduced form models. Our main concern in this paper is the effect that our state-level variables - in particular, the per capita number of restaurants - have on trends in our outcome variables, body mass index and obesity.

\section{Results}

Table 3 shows means and standard deviations of the variables. Tables 4 and 5 show results where body mass index and obese are the dependent variables. Results are pooled as well as stratified by gender. ${ }^{10}$ All regressions implement standard errors that cluster on state cells due to the aggregate nature of several of our RHS variables. The per capita number of restaurants affects females more than males in both BMI and obesity regressions. This is a poignant result, as it could reflect the increased cost of time, especially for women who are working more and have less time for meal preparation at home. An increase in the cigarette tax is shown to increase female BMI but not obesity. This is an expected result, as smoking would lower a person's BMI but not necessarily determine whether or not a person is obese. One can also think of smoking as being correlated with other unhealthy behavior, such as lack of exercise. Blacks, Hispanics, males, older people, and those who are married or widowed are more likely to have a higher BMI, while those with higher incomes and those with a college education are more likely to have a lower BMI. While males are more likely to have a higher BMI, they are less likely to be obese, reflecting the way BMI tends to overestimate overweight and obesity in people with more muscular mass. ${ }^{11}$ Looking at

\footnotetext{
${ }^{9}$ Caloric intake is based on 24-hour recall, and the measures for physical activity are not consistent across the three NHANES data sets.

${ }^{10}$ Tests for changes in coefficients across gender and race are statistically significant at the $1 \%$ level.

${ }^{11}$ Males are more likely to be overweight yet less likely to be obese.
} 
results for males and females separately, however, reveals that black males do not significantly have a higher BMI, and males with higher incomes have a higher BMI.

Elasticities of BMI in Table 6 are computed at sample means using the coefficients from the models in Table 4. The elasticities of the state-level variables are indicative, as they are based on results which include time effects yet that nevertheless do not wipe out the effects of the policy variables. The restaurant elasticity implies that as the per capita number of restaurants increases by $1 \%$, the average body mass index will rise by $0.09 \%$, holding other covariates constant. Accordingly, if the per capita number of restaurants experiences a 100 percent increase, the average body mass index will rise by $2.25 \mathrm{~kg} / \mathrm{m}^{2}$ if the mean is at $25 \mathrm{~kg} / \mathrm{m}^{2} .{ }^{12}$ The gas tax at first appeared to have a negative effect when viewing the coefficients in Tables 4 and 5, yet this switches signs at the mean, as seen in Table 6. This could mean that people do not travel as much to obtain healthier food, an added cost to preparing food at home.

A possible source of concern is the potential endogeneity of the restaurant variable. Restaurants, for example, are not randomly distributed, as they might locate themselves in areas with higher BMIs, and/or be correlated with income. This can be overlooked somewhat when we see that the rise in restaurants per capita began before the rise in obesity (see Figure 1 and Table 1). We experimented with lagged restaurants per capita (lagged three years) and found that the positive and significant effect that the per capita restaurants had on BMI and obesity did not disappear. ${ }^{13}$

By comparing the observed change in body mass index and obesity over time (in our case, between 1971 and 1994) with the predicted change based on our model, we can determine how well we have predicted BMI. According to Table 7, our model accounts for about $27 \%$ of the actual change in body mass index for the pooled model, $79 \%$ for males, and only one percent for females. Clearly there is

\footnotetext{
${ }^{12}$ Note that the average body mass index increased by $1.66 \mathrm{~kg} / \mathrm{m}^{2}$ from 1971 to 1994 (see Table 7).

${ }^{13}$ Using instrumental variables, such as female labor force participation, in an attempt to correct for the possible omitted variables bias that exists is risky, as most instruments are weak and do not pass tests for exclusion restrictions. Nevertheless, we ran models with state-level female labor force participation (and its square) as instruments for the number of restaurants (and its square). Overidentification tests could not be run as the model was exactly identified. While there were indications that the instruments were weak ( $F$ values in the first stage hovered around 3), IV results were very similar to OLS results (carrying the same sign but slightly higher in
} 
something going on with females that we have not been able to capture using this model. These values can be obtained by dividing the total predicted change with the observed change. The increase in the per capita number of restaurants makes the largest contribution to the body mass index outcome, accounting for $54 \%$ of the growth in body mass index in the pooled model. Unmeasured factors over time account for $73 \%$ of the growth in body mass index in the pooled model. In order to determine the impacts of selected factors in Table 7, we multiplied the coefficients from our samples in Table 4 with the change in that variable between 1971 and 1994, the initial and terminal years in our sample. Restaurants account for a sizeable amount of the change in BMI over time.

\section{Discussion}

Obesity is now a major epidemic in the United States that calls for immediate attention. The ready availability of inexpensive restaurants has not only caused people to consume more, but has made them less active - less likely to prepare food at home or travel further distances to obtain a healthy meal. The existence of numerous restaurants per capita facilitates caloric intake. And historically, man is conditioned to consume in order to live well. ${ }^{14}$ Technological "advances" that have made daily chores easier discourage physical activity, as does work that has increasingly become more sedentary over time.

Our model shows the rapid increase in obesity over time, especially during the 1980 s, to be due in part to the great increase in the per capita number of restaurants, and partly an unintended consequence of the campaign to reduce smoking. The increased number of restaurants could be reflective of the increased value of time for women. Possible solutions to the obesity problem might include publicly financed education about dieting and exercise, although health information does not seem be lacking and yet we still have an epidemic (Philipson 2001). If obesity is not only bad for one's health but imposes negative externalities on others, as do cigarettes, then taxing food might be a solution. ${ }^{15}$ If habits such as

magnitude, another indication of possibly weak instruments), and Durbin-Wu-Hausman tests indicated that OLS regressions were consistent.

${ }^{14}$ Obesity was once associated with wealth and power.

${ }^{15}$ As Philipson suggests, taxing food would be a regressive move, affecting the poor more than the rich (Mitka 2003). He suggests subsidizing physical activity and/or tax breaks to people joining health clubs or businesses that provide exercise opportunities to their workers. 
eating healthily and being physically active are formed from childhood, perhaps our primary focus should be on schools. Yet massive government intervention is not necessarily required. We realize that obesity is a health problem, and may be one of the costs of economic progress. We have identified the problem and recognized that we have a serious epidemic; finding a solution should be high on our agendas. 


\section{References}

Averett, S, and S Korenman. "The Economic Reality of the Beauty Myth.” Journal of Human Resources 31.2 (1996): 304-30.

Becker, GS. “A Theory of the Allocation of Time.” Economic Journal 75.299 (1965): 493-517.

Bureau of the Census, US Department of Commerce. "1972, 1982, 1987, 1992, and 1997 Census of Retail Trade.” Washington, DC: US Government Printing Office (1976).

Cawley, J. “Addiction, Calories, and Body Weight.” PhD Dissertation, University of Chicago (1999).

Cawley, J. “The Impact of Obesity on Wages.” Journal of Human Resources 39.2 (2004): 451-474.

Chou, S, M Grossman, and H Saffer. "An Economic Analysis of Adult Obesity: Results from the Behavioral Risk Factor Surveillance System.” National Bureau of Economic Research Working Paper 9247 (2002).

Chou, S, M Grossman, and H Saffer. "An Economic Analysis of Adult Obesity: Results from the Behavioral Risk Factor Surveillance System.” Journal of Health Economics 23 (2004): 565-587.

Critser, G. Fat Land: How Americans Became the Fattest People in the World. New York: Hougton Mifflin Company (2003).

Cutler, DM, EL Glaeser, and JM Shapiro. “Why Have Americans Become More Obese?” Journal of Economic Perspectives 17 (2003): 93-118.

Ewing, R, T Schmid, R Killingsworth, A Zlot, and S Raudenbush. "Relationship Between Urban Sprawl and Physical Activity, Obesity, and Morbidity." American Journal of Health Promotion 18 (2003): 47-57.

Fehily, AM, KM Phillips, and JW Yarnell. "Diet, Smoking, Social Class, and Body Mass Index in the Caerphilly Heart Disease Study.” American Journal of Clinical Nutrition 40 (1984): 827-33.

Flegal, KM, MD Carroll, CL Ogden, and CL Johnson. "Prevalence and Trends in Obesity Among US Adults, 1999-2000.” JAMA 288.14 (2002): 1723-27.

Fontaine, KR, DT Redden, C Wang, AO Westfall, and DB Allison. "Years of Life Lost Due to Obesity." JAMA 289.2 (2003): 187-93.

Frazao, E. America's Eating Habits: Changes and Consequences. Washington DC: US Department of Agriculture (1999).

Freedman, DS, LK Khan, MK Serdula, DA Galuska, and WH Dietz. "Trends and Correlates of Class 3 Obesity in the United States From 1990 Through 2000.” JAMA 288.14 (2002): 1758-61.

Freedman, DS, WH Dietz, SR Srinivasan, and GS Berenson. "The Relation of Overweight to Cardiovascular Risk Factors Among Children and Adolescents: The Bogalusa Heart Study." Pediatrics 103.6 (1999): 1175-82.

French, SA, L Harnack, and RW Jeffery. "Fast Food Restaurant Use Among Women in the Pound of Prevention Study: Dietary, Behavioral, and Demographic Correlates.” International Journal of 
Obesity 24 (2000): 1353-59.

Ippolito, PM, and AD Mathios. "Information and Advertising: The Case of Fat Consumption in the United States.” American Economic Review 85.2 (1995): 91-95.

Janssen, I, PT Katzmarzyk, and Robert Ross. "Body Mass Index, Waist Circumference, and Health Risk." Archives of Internal Medicine 162 (2002): 2074-79.

Katona, G. The Mass Consumption Society. New York: McGraw Hill, 1964.

Keeler, EB, WG Manning, JP Newhouse, EM Sloss, and J Wasserman. "The External Costs of a Sedentary Life-Style.” American Journal of Public Health 79.8 (1989): 975-81.

Koplan, JP, and WH Dietz. "Caloric Imbalance and Public Health Policy.” JAMA 282.16 (1999): 157981.

Lakdawalla, D, and T Philipson. "The Growth of Obesity and Technological Change: A Theoretical and Empirical Examination.” NBER Working Paper No. 8946 (2002).

McGinnis, JM, and WH Foege. “Actual Causes of Deaths in the United States.” JAMA 270.18 (1993): 2207-12.

Mitka, M. “Economist Takes Aim at 'Big Fat' US Lifestyle.” JAMA 289.1 (2003): 33-34.

Mokdad, AH, ES Ford, BA Bowman, WH Dietz, F Vinicor, VS Bales, and JS Marks. "Prevalence of Obesity, Diabetes, and Obesity-Related Health Risk Factors, 2001.” JAMA 289.1 (2003): 76-79.

Must, A, J Spadano, EH Coakley, AE Field, G Colditz, and WH Dietz. "The Disease Burden Associated With Overweight and Obesity.” JAMA 282.16 (1999): 1523-29.

Naik, NY, and MJ Moore. "Habit Formation and Intertemporal Substitution in Individual Food Consumption." Review of Economics and Statistics 78.2 (1996): 321-28.

National Institute of Diabetes and Digestive and Kidney Diseases. Statistics Related to Overweight and Obesity. NIH Publication No. 96-4158 ed. Washington DC: US Government Printing Office, 1996.

Nielsen, SJ, and BM Popkin. "Patterns and Trends in Food Portion Sizes, 1977-1998." JAMA 289.4 (2003): 450-53.

Peeters, A, JJ Barendregt, F Willekens, JP Mackenbach, AA Mamun, and L Bonneux. "Obesity in Adulthood and Its Consequences for Life Expectancy: A Life-Table Analysis." Annals of Internal Medicine 138.1 (2003): 24-32.

Philipson, T. "The World-Wide Growth in Obesity: An Economic Research Agenda." Health Economics 10 (2001): 1-7.

Plankey, MW, J Stevens, KM Flegal, and PF Rust. "Prediction Equations Do Not Eliminate Systematic Error in Self-Reported Body Mass Index.” Obesity Research 5.4 (1997): 308-14.

Public Health Service, US Department of Health and Human Services. The Surgeon General's Call To Action To Prevent and Decrease Overweight and Obesity. Washington, DC: US Government 
Printing Office (2001).

Rashad, I, and M Grossman. “The Economics of Obesity.” Public Interest 156 (2004): 104-112.

Raynor, HA, and LH Epstein. "Dietary Variety, Energy Regulation, and Obesity.” Psychological Bulletin 127.3 (2001): 325-41.

Rolls, BJ, and VA Hammer. "Fat, Carbohydrate, and the Regulation of Energy Intake.” American Journal of Clinical Nutrition 62 (1995):1086S-1095S.

Schlosser, E. Fast Food Nation: The Dark Side of the All-American Meal. Boston: Houghton Mifflin Company (2001).

Segal, NL, and DB Allison. "Twins and Virtual Twins: Bases of Relative Body Weight Revisited." International Journal of Obesity 26 (2002): 437-41.

Tomeo, CA, AE Field, CS Berkey, GA Colditz, and AL Frazier. "Weight Concerns, Weight Control Behaviors, and Smoking Initiation.” Pediatrics 104.4 (1999): 918-24.

\section{Acknowledgements}

Research for this paper was supported by grant number 1R01 DK54826 from the National Institute of Diabetes and Digestive and Kidney Diseases to the National Bureau of Economic Research. 


\section{Table 1}

Trends in Body Mass Index and the Percentage Obese, Persons 17 Years of Age and Older

\begin{tabular}{lccc}
\hline Survey & Period & Body Mass Index & Percentage Obese \\
\hline NHANES I & $1971-1975$ & 25.06 & 13.62 \\
NHANES II & $1976-1980$ & 25.07 & 13.67 \\
NHANES III & $1988-1994$ & 26.35 & 21.47 \\
NHANES 99 & $1999-2000$ & 27.77 & 29.19 \\
\hline
\end{tabular}

Survey weights are employed in all computations.

Table 2

Trends in Body Mass Index and the Percentage Obese, Persons 17 Years of Age and Older, By Gender

\begin{tabular}{llcccc}
\hline & \multicolumn{2}{c}{ Males } & \multicolumn{2}{c}{ Females } \\
\hline Survey & Period & $\begin{array}{c}\text { Body Mass } \\
\text { Index }\end{array}$ & $\begin{array}{c}\text { Percentage } \\
\text { Obese }\end{array}$ & $\begin{array}{c}\text { Body Mass } \\
\text { Index }\end{array}$ & $\begin{array}{c}\text { Percentage } \\
\text { Obese }\end{array}$ \\
\hline NHANES I & $1971-1975$ & 25.33 & 11.31 & 24.81 & 15.71 \\
NHANES II & $1976-1980$ & 25.22 & 11.36 & 24.94 & 15.78 \\
NHANES III & $1988-1994$ & 26.41 & 18.86 & 26.29 & 23.85 \\
NHANES 99 & $1999-2000$ & 27.49 & 25.69 & 28.04 & 32.43 \\
\hline
\end{tabular}

Survey weights are employed in all computations. 
Table 3

Definitions, Means, and Standard Deviations of Variables for Pooled Sample

\begin{tabular}{|c|c|c|}
\hline Variable & Definition & $\begin{array}{c}\text { Mean } \\
\text { (Standard } \\
\text { Deviation) }\end{array}$ \\
\hline Body mass index & Weight in kilograms divided by height in meters squared & $\begin{array}{l}25.552 \\
(5.262)\end{array}$ \\
\hline Obese & $\begin{array}{l}\text { Dichotomous variable that equals } 1 \text { if body mass index is } \\
\text { equal to or greater than } 30\end{array}$ & $\begin{array}{c}0.166 \\
(0.372)\end{array}$ \\
\hline Black non-Hispanic & $\begin{array}{l}\text { Dichotomous variable that equals } 1 \text { if respondent is black } \\
\text { but not Hispanic }\end{array}$ & $\begin{array}{c}0.105 \\
(0.307)\end{array}$ \\
\hline Hispanic & $\begin{array}{l}\text { Dichotomous variable that equals } 1 \text { if respondent is } \\
\text { Hispanic }\end{array}$ & $\begin{array}{c}0.063 \\
(0.243)\end{array}$ \\
\hline Other race & $\begin{array}{l}\text { Dichotomous variable if respondent's race is other than } \\
\text { white or black }\end{array}$ & $\begin{array}{c}0.022 \\
(0.147)\end{array}$ \\
\hline Male & Dichotomous variable that equals 1 if respondent is male & $\begin{array}{c}0.478 \\
(0.500)\end{array}$ \\
\hline Elementary & $\begin{array}{l}\text { Dichotomous variable that equals } 1 \text { if respondent completed } \\
\text { at } 8 \text { years of formal schooling }\end{array}$ & $\begin{array}{c}0.063 \\
(0.243)\end{array}$ \\
\hline Some high school & $\begin{array}{l}\text { Dichotomous variable that equals } 1 \text { if respondent completed } \\
\text { at least } 9 \text { years but less than } 12 \text { years of formal schooling }\end{array}$ & $\begin{array}{c}0.168 \\
(0.374)\end{array}$ \\
\hline High school graduate & $\begin{array}{l}\text { Dichotomous variable that equals } 1 \text { if respondent completed } \\
\text { exactly } 12 \text { years of formal schooling }\end{array}$ & $\begin{array}{c}0.352 \\
(0.478)\end{array}$ \\
\hline Some college & $\begin{array}{l}\text { Dichotomous variable that equals } 1 \text { if respondent completed } \\
\text { at least } 13 \text { years but less than } 16 \text { years of formal schooling }\end{array}$ & $\begin{array}{c}0.173 \\
(0.378)\end{array}$ \\
\hline College graduate & $\begin{array}{l}\text { Dichotomous variable that equals } 1 \text { if respondent graduated } \\
\text { from college }\end{array}$ & $\begin{array}{c}0.156 \\
(0.363)\end{array}$ \\
\hline Married & Dichotomous variable that equals 1 if respondent is married & $\begin{array}{c}0.645 \\
(0.478)\end{array}$ \\
\hline Divorced & $\begin{array}{l}\text { Dichotomous variable that equals } 1 \text { if respondent is divorced } \\
\text { or separated }\end{array}$ & $\begin{array}{c}0.085 \\
(0.278)\end{array}$ \\
\hline Widowed & $\begin{array}{l}\text { Dichotomous variable that equals } 1 \text { if respondent is } \\
\text { widowed }\end{array}$ & $\begin{array}{c}0.058 \\
(0.234)\end{array}$ \\
\hline Household income & $\begin{array}{l}\text { Real household income in tens of thousands of 1982-84 } \\
\text { dollars }\end{array}$ & $\begin{array}{l}2.907 \\
(2.395)\end{array}$ \\
\hline Age & Age of respondent & $\begin{array}{c}41.243 \\
(16.681)\end{array}$ \\
\hline Restaurants & $\begin{array}{l}\text { Number of fast-food restaurants and full-service restaurants } \\
\text { per ten thousand persons in respondent's state of residence }\end{array}$ & $\begin{array}{l}11.039 \\
(2.270)\end{array}$ \\
\hline Cigarette tax & Real state cigarette tax in $1982-84$ cents & $\begin{array}{l}22.581 \\
(9.770)\end{array}$ \\
\hline Gas tax & Real state gasoline tax in $1982-84$ cents per gallon & $\begin{array}{l}15.050 \\
(3.837)\end{array}$ \\
\hline
\end{tabular}




\begin{tabular}{llc}
\hline Variable & Definition & $\begin{array}{c}\text { Mean } \\
\text { (Standard } \\
\text { Deviation) }\end{array}$ \\
\hline Indoor & $\begin{array}{l}\text { Sum of indoor air law dichotomous variables } \\
\text { (private+government+restaurant+other) }\end{array}$ & $\begin{array}{c}\text { (1.316) } \\
\end{array}$ \\
\hline
\end{tabular}

Standard deviation in parentheses. Sample size is 42,003 . NHANES sample weights are used in calculating the mean and standard deviation. 


\section{Table 4}

Body Mass Index Regressions, Persons 17 Years of Age and Older

\begin{tabular}{|c|c|c|c|}
\hline Independent Variables & (1) Pooled & (2) Males & (3) Females \\
\hline Restaurants & $\begin{array}{l}0.473 \\
(1.46)\end{array}$ & $\begin{array}{l}-0.006 \\
(0.02)\end{array}$ & $\begin{array}{l}0.893^{*} \\
(1.73)\end{array}$ \\
\hline Restaurants squared & $\begin{array}{l}-0.012 \\
(1.05)\end{array}$ & $\begin{array}{c}0.009 \\
(0.62)\end{array}$ & $\begin{array}{l}-0.031^{*} \\
(1.66)\end{array}$ \\
\hline Cigarette tax & $\begin{array}{l}0.058^{*} \\
(1.81)\end{array}$ & $\begin{array}{l}0.022 \\
(0.56)\end{array}$ & $\begin{array}{l}0.102 * \\
(1.95)\end{array}$ \\
\hline Cigarette tax squared & $\begin{array}{l}-0.001 * * \\
(2.46)\end{array}$ & $\begin{array}{l}-0.001 \\
(0.87)\end{array}$ & $\begin{array}{l}-0.002 * * \\
(2.47)\end{array}$ \\
\hline Indoor & $\begin{array}{l}-0.031 \\
(0.44)\end{array}$ & $\begin{array}{r}0.021 \\
(0.22)\end{array}$ & $\begin{array}{l}-0.077 \\
(0.96)\end{array}$ \\
\hline Gas tax & $\begin{array}{l}-0.143^{*} \\
(1.86)\end{array}$ & $\begin{array}{l}-0.119 \\
(1.53)\end{array}$ & $\begin{array}{l}-0.196 \\
(1.55)\end{array}$ \\
\hline Gas tax squared & $\begin{array}{l}0.005 * * \\
(2.05)\end{array}$ & $\begin{array}{l}0.004 * * \\
(2.01)\end{array}$ & $\begin{array}{r}0.007 \\
(1.61)\end{array}$ \\
\hline Black non-Hispanic & $\begin{array}{l}1.375^{* * *} \\
(8.44)\end{array}$ & $\begin{array}{l}0.223 \\
(1.61)\end{array}$ & $\begin{array}{l}2.346^{* * *} \\
(10.44)\end{array}$ \\
\hline Hispanic & $\begin{array}{l}0.865^{* * * *} \\
(3.71)\end{array}$ & $\begin{array}{l}0.375 \\
(1.22)\end{array}$ & $\begin{array}{l}1.231 * * * \\
(5.74)\end{array}$ \\
\hline Other race & $\begin{array}{l}-1.384 * * * \\
(3.71)\end{array}$ & $\begin{array}{l}-1.791 * * * \\
(4.89)\end{array}$ & $\begin{array}{l}-1.093 * * \\
(2.22)\end{array}$ \\
\hline Age & $\begin{array}{l}0.326^{* * * *} \\
(19.98)\end{array}$ & $\begin{array}{l}0.268^{* * * *} \\
(18.34)\end{array}$ & $\begin{array}{l}0.363^{* * *} \\
(14.44)\end{array}$ \\
\hline Age squared & $\begin{array}{l}-0.003 * * * \\
(18.07)\end{array}$ & $\begin{array}{l}-0.003 * * * \\
(17.64)\end{array}$ & $\begin{array}{l}-0.003 * * * \\
(12.53)\end{array}$ \\
\hline Male & $\begin{array}{l}0.434 * * * \\
(4.20)\end{array}$ & & \\
\hline Elementary & $\begin{array}{l}-0.327 * * \\
(2.12)\end{array}$ & $\begin{array}{l}-0.235 \\
(1.03)\end{array}$ & $\begin{array}{l}-0.540 * * \\
(2.07)\end{array}$ \\
\hline Some high school & $\begin{array}{l}-0.160 \\
(1.31)\end{array}$ & $\begin{array}{l}0.114 \\
(0.75)\end{array}$ & $\begin{array}{l}-0.661 * * \\
(2.65)\end{array}$ \\
\hline High school graduate & $\begin{array}{l}-0.304 * * \\
(2.35)\end{array}$ & $\begin{array}{l}0.378^{* *} \\
(2.31)\end{array}$ & $\begin{array}{l}-1.163 * * * \\
(5.05)\end{array}$ \\
\hline Some college graduate & $\begin{array}{l}-0.655^{* * * *} \\
(4.12)\end{array}$ & $\begin{array}{l}0.250^{*} \\
(1.83)\end{array}$ & $\begin{array}{l}-1.734 * * * \\
(5.61)\end{array}$ \\
\hline College graduate & $\begin{array}{l}-1.268^{* * * *} \\
(7.83)\end{array}$ & $\begin{array}{l}-0.394 * * * \\
(2.59)\end{array}$ & $\begin{array}{l}-2.583^{* * * *} \\
(8.20)\end{array}$ \\
\hline Household income & $\begin{array}{l}-0.164 * * * \\
(3.19)\end{array}$ & $\begin{array}{l}0.156^{* *} \\
(2.32)\end{array}$ & $\begin{array}{l}-0.420 * * * \\
(7.48)\end{array}$ \\
\hline Household income squared & $\begin{array}{l}0.011 * * \\
(2.16)\end{array}$ & $\begin{array}{l}-0.013 * * \\
(2.20)\end{array}$ & $\begin{array}{l}0.029 * * * \\
(5.12)\end{array}$ \\
\hline Married & $\begin{array}{l}0.405 * * \\
(2.50)\end{array}$ & $\begin{array}{l}0.874 * * * \\
(6.68)\end{array}$ & $\begin{array}{l}0.065 \\
(0.26)\end{array}$ \\
\hline Divorced & $\begin{array}{l}-0.163 \\
(0.81)\end{array}$ & $\begin{array}{l}-0.074 \\
(0.33)\end{array}$ & $\begin{array}{l}0.471^{*} \\
(1.70)\end{array}$ \\
\hline
\end{tabular}




\begin{tabular}{llll} 
Widowed & $0.580^{* *}$ & $0.629 *$ & -0.258 \\
& $(2.45)$ & $(2.02)$ & $(0.86)$ \\
Constant & $14.813^{* * *}$ & $18.573^{* * *}$ & $12.351^{* * *}$ \\
& $(6.10)$ & $(6.93)$ & $(3.55)$ \\
R-square & & & \\
Sample size & 0.10 & 0.10 & 0.13 \\
\hline
\end{tabular}

Note: All regressions include state and year dummies. All regressions employ sample weights.

Absolute values of t-ratios are reported in parentheses. Huber (1967) or robust standard errors on which they are based allow for state clustering.

*Significant at the $10 \%$ level.

**Significant at the $5 \%$ level.

$* * *$ Significant at the $1 \%$ level. 


\section{Table 5}

Obese Regressions, Persons 17 Years of Age and Older

\begin{tabular}{|c|c|c|c|}
\hline Independent Variables & (1) Pooled & (2) Males & (3) Females \\
\hline Restaurants & $\begin{array}{l}0.049 * * \\
(2.57)\end{array}$ & $\begin{array}{c}0.032 \\
(1.34)\end{array}$ & $\begin{array}{l}0.064 * * \\
(2.04)\end{array}$ \\
\hline Restaurants squared & $\begin{array}{l}-0.001 * \\
(1.73)\end{array}$ & $\begin{array}{l}-0.000 \\
(0.34))\end{array}$ & $\begin{array}{l}-0.002 \\
(1.52)\end{array}$ \\
\hline Cigarette tax & $\begin{array}{l}0.004^{*} \\
(1.82)\end{array}$ & $\begin{array}{c}0.002 \\
(0.87)\end{array}$ & $\begin{array}{l}0.006 \\
(1.60)\end{array}$ \\
\hline Cigarette tax squared & $\begin{array}{l}-0.000 * \\
(1.85)\end{array}$ & $\begin{array}{l}-0.000 \\
(0.57)\end{array}$ & $\begin{array}{l}-0.000 * \\
(1.83)\end{array}$ \\
\hline Indoor & $\begin{array}{l}-0.003 \\
(0.76)\end{array}$ & $\begin{array}{c}0.001 \\
(0.23)\end{array}$ & $\begin{array}{l}-0.008 \\
(1.46)\end{array}$ \\
\hline Gas tax & $\begin{array}{l}-0.009 \\
(1.63)\end{array}$ & $\begin{array}{l}-0.008 \\
(1.42)\end{array}$ & $\begin{array}{l}-0.012 \\
(1.42)\end{array}$ \\
\hline Gas tax squared & $\begin{array}{l}0.000 * \\
(1.95)\end{array}$ & $\begin{array}{l}0.000 * * \\
(1.97)\end{array}$ & $\begin{array}{c}0.000 \\
(1.59)\end{array}$ \\
\hline Black non-Hispanic & $\begin{array}{l}0.071 * * * \\
(7.79)\end{array}$ & $\begin{array}{l}0.019 * * \\
(2.26)\end{array}$ & $\begin{array}{l}0.114 * * * \\
(9.05)\end{array}$ \\
\hline Hispanic & $\begin{array}{l}0.032 * \\
(1.84)\end{array}$ & $\begin{array}{c}0.013 \\
(0.62)\end{array}$ & $\begin{array}{l}0.045^{* *} \\
(2.24)\end{array}$ \\
\hline Other race & $\begin{array}{l}-0.051 * * \\
(2.53)\end{array}$ & $\begin{array}{l}-0.081 * * * \\
(4.17)\end{array}$ & $\begin{array}{l}-0.027 \\
(0.82)\end{array}$ \\
\hline Age & $\begin{array}{l}0.014 * * * \\
(14.76)\end{array}$ & $\begin{array}{l}0.011^{* * * *} \\
(7.09)\end{array}$ & $\begin{array}{l}0.017 * * * \\
(14.06)\end{array}$ \\
\hline Age squared & $\begin{array}{l}-0.000^{* * * *} \\
(14.86)\end{array}$ & $\begin{array}{l}-0.000^{* * * *} \\
(7.11)\end{array}$ & $\begin{array}{l}-0.000 * * * \\
(13.10)\end{array}$ \\
\hline Male & $\begin{array}{l}-0.036^{* * * *} \\
(5.77)\end{array}$ & & \\
\hline Elementary & $\begin{array}{l}-0.022 * * \\
(2.10)\end{array}$ & $\begin{array}{l}-0.019 \\
(1.13)\end{array}$ & $\begin{array}{l}-0.029 * * \\
(2.05)\end{array}$ \\
\hline Some high school & $\begin{array}{l}-0.010 \\
(1.13)\end{array}$ & $\begin{array}{c}0.016 \\
(1.18)\end{array}$ & $\begin{array}{l}-0.044 * * \\
(2.63)\end{array}$ \\
\hline High school graduate & $\begin{array}{l}-0.024 * * \\
(2.32)\end{array}$ & $\begin{array}{c}0.019 \\
(1.20)\end{array}$ & $\begin{array}{l}-0.072 * * * \\
(4.83)\end{array}$ \\
\hline Some college graduate & $\begin{array}{l}-0.052^{* * * *} \\
(4.98)\end{array}$ & $\begin{array}{l}-0.006 \\
(0.44)\end{array}$ & $\begin{array}{l}-0.101 * * * \\
(6.15)\end{array}$ \\
\hline College graduate & $\begin{array}{l}-0.088^{* * * *} \\
(7.56)\end{array}$ & $\begin{array}{l}-0.045^{* * * *} \\
(3.47)\end{array}$ & $\begin{array}{l}-0.146^{* * * *} \\
(7.56)\end{array}$ \\
\hline Household income & $\begin{array}{l}-0.016^{* * * *} \\
(4.23)\end{array}$ & $\begin{array}{l}-0.006 \\
(1.10)\end{array}$ & $\begin{array}{l}-0.024 * * * \\
(5.54)\end{array}$ \\
\hline Household income squared & $\begin{array}{l}0.001^{* * * *} \\
(2.90)\end{array}$ & $\begin{array}{c}0.001 \\
(0.93)\end{array}$ & $\begin{array}{l}0.002 * * * \\
(3.69)\end{array}$ \\
\hline Married & $\begin{array}{c}0.013 \\
(1.12)\end{array}$ & $\begin{array}{l}0.032 * * \\
(2.22)\end{array}$ & $\begin{array}{l}-0.001 \\
(0.08)\end{array}$ \\
\hline Divorced & $\begin{array}{l}-0.007 \\
(0.50)\end{array}$ & $\begin{array}{l}-0.017 \\
(1.06)\end{array}$ & $\begin{array}{l}-0.011 \\
(0.63)\end{array}$ \\
\hline
\end{tabular}




\begin{tabular}{llll} 
Widowed & 0.028 & 0.024 & 0.001 \\
& $(1.58)$ & $(0.80)$ & $(0.08)$ \\
Constant & $-0.456^{* * *}$ & $-0.388^{* *}$ & $-0.532^{* * *}$ \\
& $(3.30)$ & $(2.11)$ & $(2.71)$ \\
R-square & & & \\
Sample size & 0.05 & 0.04 & 0.07 \\
\hline
\end{tabular}

Note: All regressions include state and year dummies. All regressions employ sample weights.

Absolute values of $t$-ratios are reported in parentheses. Huber (1967) or robust standard errors on which they are based allow for state clustering.

*Significant at the $10 \%$ level.

**Significant at the $5 \%$ level.

$* * *$ Significant at the $1 \%$ level. 
Table 6

Elasticities of Body Mass Index with Respect to Selected Variables

\begin{tabular}{lccc}
\hline Independent Variable & Pooled & Males & Females \\
\hline Restaurants & 0.090 & 0.083 & 0.091 \\
Cigarette tax & 0.011 & -0.021 & 0.011 \\
Gas tax & 0.004 & 0.001 & 0.009 \\
Income & -0.011 & 0.009 & -0.028 \\
Age & 0.127 & 0.036 & 0.186 \\
\hline
\end{tabular}

Computed at weighted sample means. 


\section{Table 7}

Impacts of Selected Factors on Body Mass Index, Persons 17 Years of Age and Older, 1971-1994

\begin{tabular}{lccc}
\hline Factor & $\begin{array}{l}\text { Pooled } \\
\text { Observed Change }=1.662 \\
(1994 \text { average }-1971 \\
\text { average })\end{array}$ & $\begin{array}{l}\text { Males } \\
\text { Observed Change }=1.238 \\
(1994 \text { average }-1971 \\
\text { average })\end{array}$ & $\begin{array}{l}\text { Females } \\
\text { Observed Change }=2.046 \\
(1994 \text { average }-1971 \\
\text { average })\end{array}$ \\
\hline Race/Ethnicity & -0.013 & -0.027 & -0.019 \\
Schooling & -0.159 & -0.034 & -0.338 \\
Marital status & -0.054 & -0.085 & 0.025 \\
Age & 0.062 & 0.029 & 0.036 \\
Household income & -0.053 & 0.023 & -0.193 \\
Restaurants & 0.904 & 0.837 & 0.913 \\
Cigarette tax & -0.113 & 0.207 & -0.103 \\
$\begin{array}{l}\text { Indoor air laws } \\
\text { Gas tax }\end{array}$ & -0.062 & 0.042 & -0.153 \\
\hline $\begin{array}{l}\text { Total predicted } \\
\text { change }\end{array}$ & -0.071 & -0.013 & -0.139 \\
\hline
\end{tabular}

Note: Impacts of selected factors obtained by multiplying coefficients from pooled models by the observed change of that factor between 1971 and 1994. 


\section{Figure 1}

Restaurants per 10,000 population, 1972-1997

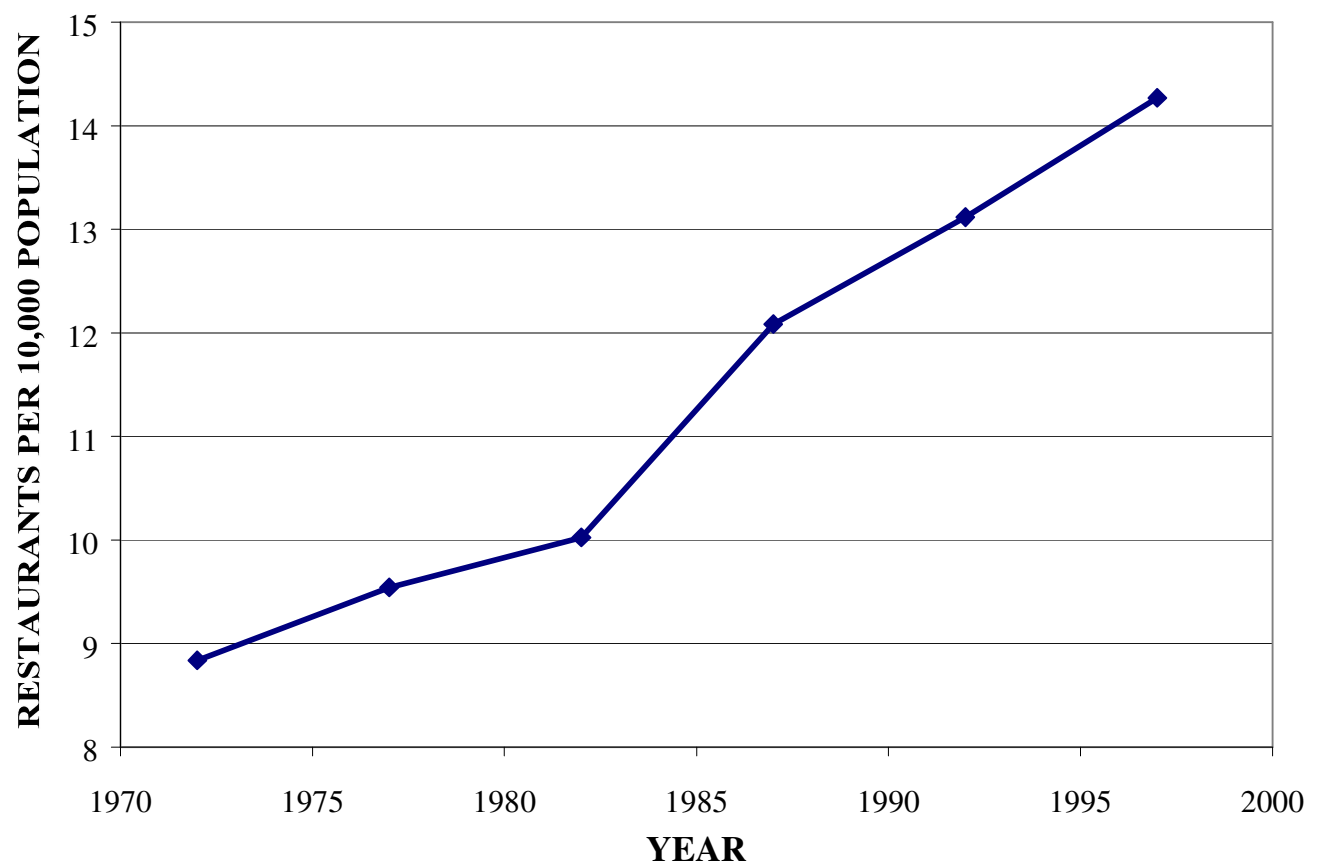

Source: Bureau of the Census (various years) 


\section{Figure 2}

Female Labor Force Participation, Ages 16 and over, 1970-2000

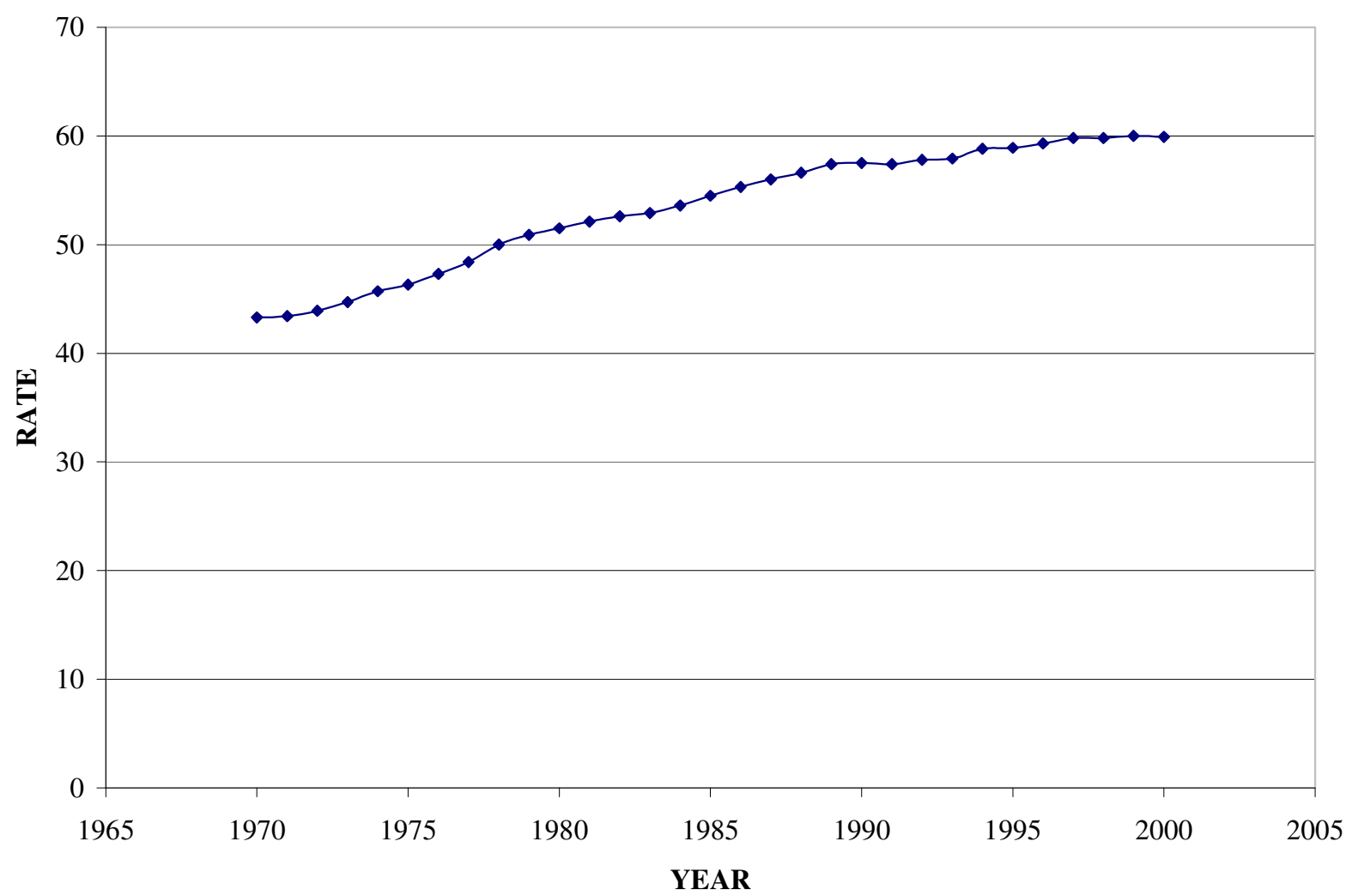

Source: Bureau of Labor Statistics 